\title{
Imagination and Research on the College English Listening Course with Speculative Teaching
}

\author{
Li Jiang \\ Jingdezhen Ceramic Institute, Jingdezhen, Jiangxi 333403, China
}

\section{Keywords: College English listening teaching; Speculative teaching}

\begin{abstract}
As a result of the reform of English scores in college entrance examination, the college English listening course has also been affected to varying degrees. How to effectively improve students' English listening ability has become the primary problem in college English listening teaching. The author puts forward the reform of college English listening curriculum based on the aim of speculative teaching and to explore the students' English listening ability.

In the context of international talent competition and intense competition, if taking the analysis of problems and problem-solving thinking as the goal of education, this comprehensive, migratory, systematic ability can be able to make students get benefit in life. The cultivation of speculation in the west is becoming more and more important, the speculative ability is regarded as a core skill of higher education, and the curriculum aiming at training speculative ability is integrated into the whole teaching plan. Especially, many colleges and universities in the United States, taking the cultivation of speculative ability as the important task of higher education.

The focus on speculative thinking in our foreign language community began with Huang Yuanshen's discussion of "thinking about absenteeism". In his article, he pointed out the performance of foreign language students the lack of speculation in China. Since then, there have been scholars to participate in the relevant discussion, or elaborate the urgency of the cultivation of speculative thinking, or reflect on teaching and analyze the reasons, or to carry out empirical research, or teaching reform. After nearly 20 years efforts of foreign language colleagues, cultivate speculation seems to be "deeply rooted in people's heart", and even become a "fashion" of foreign language teaching reform.

Listening is the first position of four basic skills in foreign language teaching. According to the scientific survey, people in the use of language communication process, listening activities accounts for $45 \%$. At present, there are some problems in college English listening teaching, while most students believe that English listening is indeed the most difficult to overcome. I put some of my own views on this issue.
\end{abstract}

\section{Research Background}

This year in October, the Beijing Municipal Education Commission announced the reform program in college entrance examination, college entrance examination of English course reduced from 150 to 100 points. As the score changes, the degree of emphasis on English language is also reduced to varying degrees. This objective fact makes many teachers, especially university teachers have a different response. I believe that China is to strengthen the important position of the mother tongue, but English is still the world's leading language. As English scores of the college entrance examination change, directly leading to college English teaching mode changes. The author of the institutions also strive to focus on student practice, cultivate the direction of professional personnel, the corresponding English class can be reduced.

In such circumstances, college English should also focus on training students in listening and speaking ability and reading ability, can really apply the English language.

Then the college English listening and speaking course is particularly important, as to the college English listening course, the author made the initial reform. 


\section{The Current Situation of Listening Teaching in English}

After the college entrance examination for students into the university, still need to pass College English Band Four examinations, listening is a high score in the exams, directly impacting on rate of student passing. China is still strengthening cooperation with the international community, English listening is undoubtedly a high demand, so that the high demand for English listening teaching is required.

At present, college English listening teaching is still the main teaching, listening to the recording and then find the answer, resulting in students gradually losing interest in English listening. Through the analysis of university English four grades in 2009, it is found that the loss rate of hearing is the highest one in the examination, which affects the students' test scores. We also conducted a survey of 246 students in the School of Materials in 2016. About $40.1 \%$ of the students considered hearing to be more important. $81.3 \%$ of the students thought it is necessary to improve their English listening level.

\section{Speculative Listening}

Speculation, or critical thinking, is a way of thinking. It is both a skill and a habit, not limited to subjects or content (Scriven \& Paul, 2008). Speculative ability in Listening comprehension, and speaking, reading, writing process need to cultivate have the same essence. The lag of listening comprehension research is related to the characteristics of hearing research and the characteristics of hearing itself. Listening is the acceptance of skills, not like to speak and write that will output, the process and results in listening can not be heard, which brings some difficulty to the study. Oral language is sound coding, no space can be segmented vocabulary, accompanied by accent, speed and other changes; it has real-time characteristics, requiring the listener to process information online. These factors make learners feel listening often the most difficult course (Graham, 2006). In the process of listening to critical thinking, many learners is no time to take into account. Therefore, we feel that there is an urgent need to strengthen the specialized ability of listening comprehension. Proposal of the listening ability, not only means a new perspective, but also means that the new tasks and requirements. To improve the ability of listening comprehension: (1) to improve the input process of speculative ability, is to improve the output process speculative ability of a solid foundation; (2) in the development of high-level thinking ability, at the same time, to promote listening comprehension ability on a higher level, but also to improve the ability of listening comprehension, to form mutual promotion; (3) to encourage learners to take independent thinking, self-dialogue, self-judgment, is conducive to sound personality development.

Lorin Anderson (1990) has made same change for improving the classification of cognitive ability of the former, and proposed a 6-level model: (Figure 1)

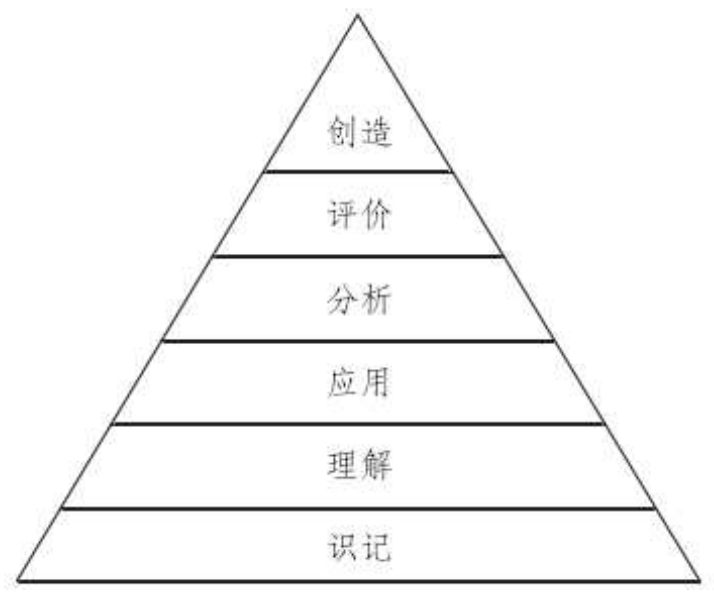

Creation/Evaluation/Analysis/Application/ Understanding/Remember

Figure 1. Lorin Anderson cognitive ability model classification chart 


\section{Research Objects and Methods}

Objects. In September 2016 the author selected 2 parallel classes in College of Materials for pre-school hearing tests, the two classes were equal. One is the experimental class, another one is its control class.

Methods. From September 2016 to May 2017, the duration of the school year was 32 hours. The control class still takes the traditional listening teaching, one class every week, listening to the recording and check the answer. The following classes were reformed by Lorin Anderson's model of the cognitive model

The previous task before listening. Speculative listening task is divided into three steps, the goal is to strengthen the students' minds and understanding ability, one is pre-class reading preview. Require students to do a preview in a timely manner, learning about the basic contents of the classroom to prepare the understanding of cultural issues later. Second, the background and cultural understanding and vocabulary preparation before listening, show students the video, the people discussed on the cultural phenomenon of their own views, in order to allow students to fully understand the cultural connotation, teachers can also make a preparation for 10 minutes, to talk about their views on this culture, enhance students' comprehensive language application ability, and to compare the analysis of cultural differences, training students' analytical skills. Third is the practice first time to listen based on the basic skills. Ask the students some questions about what they are listening to. These activities make the speculative task fully guided.

Listening Classes - Student is the center. Listening teaching is a complicated process. Teachers should take students as the main body, guide students, determine students' learning objectives, improve students' listening interests, and make students understand the listening materials by listening and speaking. Listening teaching classroom only depend on 32 hours, it is far from enough to improve students' listening ability. It is necessary to guide students to effectively use the textbook content in the classroom to improve listening ability. Repeatedly, every time you do the following skills to do specialized training: $\bullet$ basic thinking listening skills such as perception, understanding - advanced thinking skills such as analysis and evaluation - speculative ability such as self-assessment, self-correcting teachers according to students listening ability to group students.

Emphasis on the results of learning. The practice after listening take the various forms of dialogue between as the main content, the contents of the hearing materials involved in the culture of Chinese and foreign cultures cross-cultural comparison, on the one hand, both consider the interpersonal listening level, on the one hand, do some supplements in the cultural level of speculative ability. In order to effectively carry out a series of teaching measures, teachers can count the situation of students in the experimental class and extracurricular learning into the usual performance assessment, urging students to continue to learn.

\section{Results}

Through one year of experimental teaching, the control class and the experimental class students in the examination, the experimental class students did improve the listening performance. Therefore, the reform of college English listening curriculum is still successful, but this is not enough, in the subsequent teaching of listening we should further reform it so that the listening level of students get improved.

\section{Acknowledgement}

Fund Project: Jingdezhen Ceramic University Teaching Reform Research Fund Project

\section{References}

[1] Q.F. Wen, etc. China's English majors and other liberal arts student speculative ability comparison [J]. Foreign Language Teaching and Research, 2010 (5): 350-355.

[2]Y.Z. Sun. Outstanding speculative ability training, English teaching reform will lead in depth [J]. 
Chinese Foreign Language, 2011 (3): 49-58.

[3] Y.Z. Sun. English professional writing teaching and speculative ability training forum [J]. Foreign Language Teaching and Research, 2011 (4): 603-608.

[4] Y. Lin. Oral English teaching and speculative ability training - A study on students' reflection log in English debate course [J]. Foreign Language and Foreign Language Teaching, 2012 (5): 29-33.

[5] J. Wang. Metacognitive knowledge in the process of cultivating speculative in the reading of the ability [J]. Contemporary foreign language research, 2012 (8): 37-40.

[6] W. Ren. Discussion on the foreign language student speculative ability: "absent" or "presence"? and discussion on the integration of speculative ability into foreign language professional education process - taking English lectures as an example [J]. Chinese Foreign Language, 2013 (1): 10-17. 